\title{
Rotátorköpeny-szakadás után kialakult zsíros degeneráció változása az ín rekonstrukcióját követően, 65 éves kor után
}

\author{
Sallai Imre dr. - Weidl Márton dr. - Szatmári Attila dr. \\ Antal Imre dr. - Skaliczki Gábor dr. \\ Semmelweis Egyetem, Általános Orvostudományi Kar, Ortopédiai Klinika, Budapest
}

\begin{abstract}
Bevezetés: A rotátorköpeny-szakadás következménye az izom atrófiája és zsíros degenerációja. Ezek mértéke befolyásolja az ín rekonstruálhatóságát és a mútét utáni funkciót.

Célkitüzés: Degeneratív szakadások rekonstrukciója után vizsgáltuk az izomállomány változását és ennek összefüggését a posztoperatív funkcióval 65 év feletti betegeknél.

Módszer: A Semmelweis Egyetem Ortopédiai Klinikáján artroszkópos rotátorköpeny rekonstrukciók utánkövetését végeztük. A vizsgálatba tizenegy, 65 év feletti beteg került bevonásra; az átlagos utánkövetési idő 39,9 hónap, a betegek átlagéletkora 71,9 év volt. A szakadás mérete szerint $3 \mathrm{Cl}, 3 \mathrm{C} 2,4 \mathrm{C} 3$ és 1 C4 volt. Minden betegnél mútét előtti és mútét utáni mágnesesrezonancia-vizsgálat elemzése, vizuális analóg skála és Constant-pontszám meghatározása történt.

Eredmények: A posztoperatív átlagos Constant-érték 75 pont volt. Az izomatrófiára utaló értékek és a zsíros degeneráció nem mutattak szignifikáns javulást.

Következtetés: A vizsgálat szerint a rotátorköpeny-szakadás 65 év felett végzett rekonstrukciója után az izomállomány zsíros degenerációja és atrófiája progrediál, az eredmények alapján ugyanakkor jó funkciót biztosít az ín rekonstrukciója.

Orv Hetil. 2019; 160(14): 533-539.
\end{abstract}

Kulcsszavak: rotátorköpeny, mútéti kezelés, zsíros degeneráció, izomatrófia

\section{The change of fatty degeneration in the rotator cuff muscles after repair in patients over 65}

Introduction: In the case of rotator cuff tears, the severity of the muscle atrophy and fatty degeneration has an effect on the success of the repair and on the functional outcome after surgery.

Aim: The ability of regeneration reduces with ageing; therefore, the study examined the atrophy and the fatty degeneration after rotator cuff repair in patients over 65.

Method: Eleven patients over 65 years of age were involved whose surgery was performed at the Department of Orthopaedics of Semmelweis University between 2012 and 2015. Their average age was 71.9 years and the average follow-up period was 39.9 months. Tear sizes were $\mathrm{C} 1$ in 3 cases, $\mathrm{C} 2$ in 3 cases, $\mathrm{C} 3$ in 4 cases, and C4 in 1 case. Each patient had magnetic resonance examination before and after the repair; the muscle atrophy and fatty degeneration were evaluated together with the type of the tear. Visual analogue scale and Constant score were used for the assessment of the pain and the shoulder function.

Results: The average Constant score was 75 points. The occupancy ratio - referring to the severity of the atrophy did not show significant improvement. The change in fatty degeneration and the atrophy were examined in different groups according to the size of the tears. In each group, the results showed progression.

Conclusions: After rotator cuff repair in patients over 65, fatty degeneration and muscle atrophy also show progression. No significant relationship was found between the size of the tear and fatty degeneration or between the size of the tear and muscle atrophy.

Keywords: rotator cuff surgery, fatty degeneration, muscle atrophy 
Sallai I, Weidl M, Szatmári A, Antal I, Skaliczki G. [The change of fatty degeneration in the rotator cuff muscles after repair in patients over 65]. Orv Hetil. 2019; 160(14): 533-539.

(Beérkezett: 2018. október 14; elfogadva: 2018. október 31.)

\section{Rövidítések}

CS $=($ Constant-Murley Score $)$ Constant-pontszám; MRI = (magnetic resonance imaging) mágnesesrezonancia-vizsgálat; $\mathrm{OR}=($ occupancy ratio $)$ kitöltöttségi arány; $\mathrm{ROK}=$ rotátorköpeny; VAS = vizuális analóg skála

A glenohumeralis ízületet körülvevő, annak közvetlen mozgatásáért felelős rotátorköpeny-izomcsoport inas lemezének tapadási helye a humerus tuberculum maius és minus anatómiai pontjai. A rotátorköpeny funkciója a mozgások biztosításán túl a humerusfej centralizált pozícióban tartása a scapula ízvápájában. Teljes vastagságú rotátorköpeny-szakadás során az inas lemez retrakciójával az ín és az izomrostok közötti húzási vektor (pennation angle) iránya is megváltozik [1]. A degeneratív jellegú szakadások a leggyakrabban a musculus (m.) supraspinatus inat érintik [2]. A szakadás az ín retrakcióján túl az izom állományának atrófiájához, zsíros degenerációjához [3], valamint az ismert erőpárok centralizáló hatásának megbomlásával $[4,5]$ a humerusfej proximalis irányba való migrációjához vezet. Ezáltal teljes vastagságú szakadás következtében a glenohumeralis ízületet körülvevő képletek struktúrája, valamint az ízület teljes biomechanikája is megváltozik [6].

A rotátorköpeny-szakadás diagnózisának felállítása céljából végzett MR-vizsgálat [7] a szakadás verifikálásán és az ínretrakció megítélésén túl lehetőséget biztosít arra is, hogy az érintett izom atrófiáját [8] és zsíros degenerációjának mértékét meghatározzuk $[9,10]$. Ezen információk alapján preoperatíve nagy valószínúséggel megítélhető az ínnak a tapadási helyére való visszahúzhatósága, annak rekonstruálhatósága, valamint a rekonstrukció utáni gyógyhajlam, esetlegesen a reruptura veszélye. A degeneratív ín és az atrofizált, zsíros degeneráció miatt megváltozott struktúrájú izom mobilizálhatósága csökken, regenerációs képessége alacsony, a rögzítőfonalakat ezek a szövetek kevésbé tarthatják meg, így megnő a reruptura veszélye.

Gerber és mtsai [11] kutatásaik során azt a megállapítást tették, hogy a rotátorköpeny-rekonstrukció ellenére a zsíros degeneráció és az izomatrófia mértéke nem csökken, vagyis az izom minősége és állománya a rekonstrukció ellenére nem mutat jelentős javulást. A betegek mindennapi fájdalmai és életminősége azonban a rekonstrukció után jelentősen javul a mütét előtti állapotukhoz viszonyítva [12].

Vizsgálatunkat azzal a céllal terveztük meg, hogy ellenőrizzük a 65 év feletti artroszkópos rotátorköpenyrekonstrukción átesett betegeinket. Kíváncsiak voltunk az életminőségükre, funkcionális eredményükre, valamint a rekonstruált ínhoz tartozó izom minőségi (zsíros degeneráció) és mennyiségi (atrófia) változásaira. Megvizsgáltuk, hogy található-e szignifikáns összefüggés a rotátorköpeny rekonstrukció utáni állapota, valamint a betegek mütét utáni középtávú életminőség- és fájdalomértékei között, továbbá hogy milyen összefüggést mutat a zsíros degeneráció változása a mütét utáni funkcionális eredményekkel.

\section{Módszer}

Retrospektív vizsgálatunkba a Semmelweis Egyetem Ortopédiai Klinikáján 2012 és 2015 között tizenegy, 65 év feletti, degeneratív rotátorköpeny-szakadás miatt artroszkópos rotátorköpeny-rekonstrukción átesett beteget vontunk be. A mütét után eltelt átlagos utánkövetési idő 39,9 hónap (26-52 hónap), a vizsgálatba bevont páciensek átlagéletkora 71,9 év (69-77 év) volt. A 11 vizsgált betegből 7 nő és 4 férfi volt. Minden betegnél a m. supraspinatus ín szakadása állt fenn. A rotátorköpeny rekonstrukciójakor mind a 11 beteg esetében egy darab, két pár fonalat tartalmazó felszívódó vagy nem felszívódó horgonnyal egysoros két darab matracöltéssel történt a rögzítés. A szakadás minden esetben teljes vastagságú (C-típusú) volt, de különböző méretű. A méret szerinti megoszlást illetően: 3 (27\%) esetben volt Cl-, 3 (27\%) esetben C2-, 4 (37\%) esetben C3- és 1 (9\%) esetben C4[13] típusú szakadás; az esetek $82 \%$-ában a domináns oldalt érintette a szakadás (1. táblázat). Vizsgálatunkba csak olyan betegeket vontunk be, akiknél a mútét előtti képalkotó vizsgálatok képanyaga rendelkezésre állt.

A vizsgálatban részt vevőkkel való konzultáció után MR-vizsgálatra jegyeztük elő, majd annak elkészült képanyagát értékelve kontrolláltuk őket. Fizikális vizsgálattal lemértük a mütött és az egészséges váll mozgástartományát, a rotátorköpeny intaktságának megítélésére szolgáló funkcionális teszteket végeztünk, valamint kikérdeztük őket a mindennapi életben esetlegesen fennálló fájdalomról és panaszokról, amelyek a vállat érintő funkciózavarral hozhatók összefüggésbe. A fájdalom mértékét a betegek vizuális analóg skálán (VAS) jelölték. Ez alapján a fájdalom mértéke lehet kiváló (0-2), jó (3-4), közepes (5-6) vagy rossz (7-10).

Betegeink emellett életminőség-kérdőívet is kitöltöttek. A felvett adatokat, a mozgástartományokat és a célzott teszteket - ahol lehetőség nyílt rá - összehasonlítottuk az operáció előtti értékekkel. Továbbá, szintén a felvett adatok alapján, kiszámoltuk az egyes betegek Constant- (vagy Constant-Murley-) pontszámát. 
1. táblázat |A betegek megoszlása a szakadás súlyosságának függvényében

\begin{tabular}{lcccc}
\hline Szakadás típusa (C) & $\begin{array}{c}\text { C1 } \\
\text { Kisméretû́ „tűszúrás” } \\
\text { szakadás }\end{array}$ & $\begin{array}{c}\text { C2 } \\
2 \mathrm{~cm} \text { alatt, egy inat } \\
\text { érint, nincs retrakció }\end{array}$ & $\begin{array}{c}\text { C3 } \\
3-4 \text { cm nagyságú, } \\
\text { kismértékű retrakcióval }\end{array}$ & $\begin{array}{c}\text { C4sszesen } \\
\text { több inat érint, nagy retrakció }\end{array}$ \\
\hline Betegszám & 3 & 3 & 4 & 1 \\
\hline
\end{tabular}

A Constant-pontszám (Constant score - CS) a váll funkcionális állapotáról jó képet ad, hiszen több, a mindennapi élethez szükséges mutatót is figyelembe vesz [14]. A számítás során a fájdalom, a napi tevékenységek elvégzésének képessége, az abdukció, az eleváció, a funkcionális ki- és berotáció, illetve az izomerő a legfontosabb megvizsgálandó adatok. A CS-t kiválónak minősítjük, ha 100-80, jónak 79-65 között, közepesnek 64-55 között és rossznak 55 alatti pontszám esetén.

Az ínretrakció, az atrófia és a zsíros degeneráció mértékének vizsgálatához - egyúttal a preoperatív állapottal való összehasonlításhoz - a betegek mütét előtti és mütét utáni MR-vizsgálatát használtuk fel. Az MRI-felvételek elemzését, illetve a méréseket az IMPAX Client program segítségével végeztük.

Az ín retrakcióját az MRI frontalis síkban készült rekonstrukciós képein határozhatjuk meg a Patte-klasszifikáció szerint [15].

Az izomatrófiát a Thomazeau-féle occupancy ratio (OR), vagyis a kitöltöttségi arány kiszámolásával végeztük. A sagittalis síkban készült rekonstrukciós képen a m. supraspinatus izomállományának felületét (A) és a fossa

2. táblázat |A betegek száma és a posztoperatív Constant-pontszám

\begin{tabular}{lcc}
\hline Constant-pontszám & Betegek száma & $\%$ \\
\hline Kiváló $(100-80)$ & 5 & 45,45 \\
Jó $(79-65)$ & 4 & 36,35 \\
Közepes $(64-55)$ & 1 & 9,1 \\
Rossz $(55>)$ & 1 & 9,1 \\
\hline
\end{tabular}

3. táblázat |A szakadás mérete és a posztoperatív Constant-pontszám

\begin{tabular}{cc}
\hline Constant-szám & Szakadás mérete $(\mathrm{C})$ \\
\hline 66 & 3 \\
65 & 4 \\
95 & 1 \\
60 & 2 \\
78 & 3 \\
87 & 3 \\
94 & 3 \\
65 & 2 \\
47 & 2 \\
80 & 1 \\
85 & 1 \\
\hline
\end{tabular}

supraspinata teljes felületét $(\mathrm{B})$ arányosítjuk: $\mathrm{R}=\mathrm{A} / \mathrm{B}$. A beosztás három stádiumra osztja az izomatrófia mértékét. Az egyes stádium, amikor az izomállomány normális, vagy enyhén atrofizált, ekkor az OR 1 és 0,6 közötti. A kettes stádium a mérsékelt atrófia, az OR: 0,59-0,4. A hármas stádium esetén súlyos atrófiáról beszélünk, ekkor az OR <0,39 [16].

A zsíros degeneráció mértékét a Goutallier-féle négyes fokozatú skálán értékeltük [17].

\section{Eredmények}

A mütét után 2-5 évvel a betegek $81 \%$-a kiváló vagy jó CS-értékekkel rendelkezik. Betegeink CS-átlaga 75 volt, 47 és 95 közötti tartományban. Ez a tartomány 6 (55\%) 80 alatti és 5 (45\%) 80 fölötti értékból adódott össze (2. táblázat). A posztoperatív CS és a kiindulási szakadás mértéke között nem állt fenn egyenes arányosság (3. táblázat, 1. ábra).

A preoperatív OR-értékek a posztoperatív eredményekkel összehasonlítva nem mutattak szignifikáns mértékű javulást. Az adatokat $\mathrm{p}=0,05$-ös szignifikanciahatár mellett vizsgáltuk párosított t-próba használatával, ahol a p értéke 0,1093 lett. Az OR értékeiben bekövetkezett változás átlaga $-0,0567$ volt, 0,1070-es szórással. A 11 beteg közül az atrófia mértéke $6(55 \%)$ esetben növekedett, és 5 (45\%) esetben csökkent (4. táblázat).

Összefüggés az inretrakcióval: mivel az ínretrakció mértéke befolyásolja a ín rekonstruálhatóságát, azt is elemeztük, hogy az ínretrakció súlyossága az operációt megelőzően (Patte osztályozása szerint) mutat-e összefüggést a OR-ban bekövetkező változással vagy a zsíros degeneráció súlyosságával, vagyis a nagyobb mértékü preoperatív ínretrakció befolyásolja-e a rekonstrukció utáni izomatrófia vagy a zsíros degeneráció mértékét. A Pearson-féle korrelációs próbával vizsgálva azonban

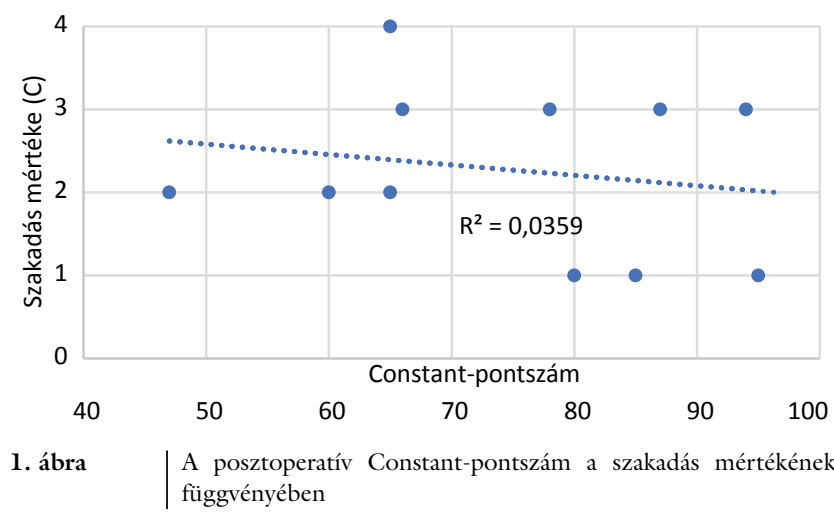


4. táblázat |A preoperatív és a posztoperatív OR közötti változások

\begin{tabular}{|c|c|c|c|}
\hline \multicolumn{2}{|c|}{ Kitöltöttségi arány } & & \multirow{2}{*}{$\begin{array}{l}\text { Változás } \\
\text { mértéke }\end{array}$} \\
\hline preoperatív & posztoperatív & & \\
\hline 0,64 & 0,69 & & 0,05 \\
\hline 0,59 & 0,48 & & $-0,11$ \\
\hline 0,48 & 0,38 & & $-0,1$ \\
\hline 0,67 & 0,4 & & $-0,27$ \\
\hline 0,61 & 0,52 & & $-0,09$ \\
\hline 0,42 & 0,46 & & 0,04 \\
\hline 0,45 & 0,506 & & 0,056 \\
\hline 0,55 & 0,38 & & $-0,17$ \\
\hline 0,59 & 0,64 & & 0,05 \\
\hline 0,63 & 0,64 & & 0,01 \\
\hline 0,67 & 0,58 & & $-0,09$ \\
\hline \multirow[t]{2}{*}{$\begin{array}{l}\text { Szignifikancia } \\
(\mathrm{p}<0,05)\end{array}$} & 0,1093 & $\begin{array}{l}\text { Változás } \\
\text { átlagos mértéke }\end{array}$ & $-0,0567$ \\
\hline & & $\begin{array}{l}\text { Változás } \\
\text { szórása }\end{array}$ & 0,1070 \\
\hline
\end{tabular}

$\mathrm{OR}=$ kitöltöttségi arány

egyik posztoperatív mutatóval sincs szignifikáns korreláció. Az r értéke az OR esetében 0,1153, a zsíros degeneráció esetében pedig 0,1352 volt (2. és 3. ábra).

Összefüggés a szakadás súlyosságával: megvizsgáltuk az izomatrófia mértékét a szakadás súlyosságának függvényében. A betegeket három csoportba osztottuk be annak alapján, hogy enyhe (C1), mérsékelt (C2) vagy masszív (C3-4) ROK-szakadásuk volt. Az enyhe súlyosságú szakadás esetében a preoperatív és a posztoperatív OR átlagai közötti különbség -0,0533, a mérsékelt szakadás esetében $-0,1067$, súlyos szakadás esetében pedig $-0,0288$ volt. A negatív értékek mindhárom csoportban az atrófia súlyosbodására utalnak. Az OR közötti változás egyik csoportban sem volt szignifikáns. Az adatokat ebben az esetben is párosított t-próbával vizsgáltuk, $\mathrm{p}=$ 0,05-ös szignifikanciahatár mellett (5. táblázat).

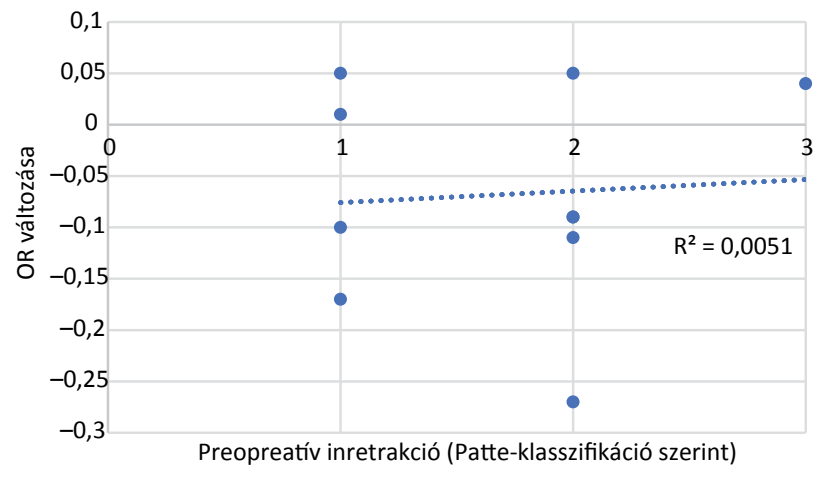

\begin{tabular}{l|l} 
2. ábra & $\begin{array}{l}\text { Az OR változása és a preoperatív ínretrakció összefüggése } \\
\text { OR = kitöltöttségi arány }\end{array}$
\end{tabular}

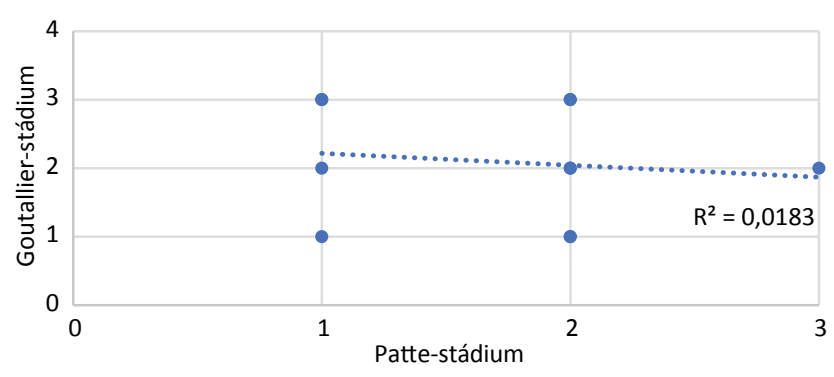

3. ábra $\quad$ A posztoperatív zsíros degeneráció mértéke a preoperatív ínretrakció függvényében

Ugyanilyen csoportokban megnéztük a zsíros degeneráció változását is, a Goutallier-klasszifikáció szerinti stádiumok használatával. A zsíros degeneráció mindhárom csoportban súlyosbodott; a változás átlaga az enyhe csoportban volt a legnagyobb és a mérsékelt csoportban a legkisebb. A mérsékelt és a súlyos csoportban 4 (36\%) alkalommal fordultak elő olyan esetek, hogy a zsíros degeneráció a klasszifikáció stádiuma szerint nem változott, de egyik csoporton belül sem következett be a zsíros degeneráció javulása (6. táblázat).

5. táblázat |Az OR különbsége különböző súlyosságú szakadások esetén

\begin{tabular}{|c|c|c|c|c|c|c|}
\hline & \multicolumn{2}{|c|}{ Enyhe } & \multicolumn{2}{|c|}{ Mérsékelt } & \multicolumn{2}{|c|}{ Masszív } \\
\hline & preoperatív & posztoperatív & preoperatív & posztoperatív & preoperatív & posztoperatív \\
\hline & 0,64 & 0,69 & 0,67 & 0,4 & 0,45 & 0,506 \\
\hline & 0,59 & 0,48 & 0,61 & 0,52 & 0,55 & 0,38 \\
\hline & 0,48 & 0,38 & 0,42 & 0,46 & 0,59 & 0,64 \\
\hline & & & & & 0,63 & 0,64 \\
\hline & & & & & 0,67 & 0,58 \\
\hline Átlag & 0,5700 & 0,5167 & 0,5667 & 0,4600 & 0,5780 & 0,5492 \\
\hline STD & 0,0819 & 0,1582 & 0,1305 & 0,0600 & 0,0844 & 0,1095 \\
\hline Átlag különbsége & \multicolumn{2}{|c|}{$-0,0533$} & \multicolumn{2}{|c|}{$-0,1067$} & \multicolumn{2}{|c|}{$-0,0288$} \\
\hline p-érték & \multicolumn{2}{|c|}{0,4110} & \multicolumn{2}{|c|}{0,3572} & \multicolumn{2}{|c|}{0,5478} \\
\hline
\end{tabular}

OR = kitöltöttségi arány 


\begin{tabular}{lc|c|c|c|c|c}
\hline & \multicolumn{2}{c|}{ Enyhe } & \multicolumn{2}{c}{ Mérsékelt } & \multicolumn{2}{c}{ Masszív } \\
\cline { 2 - 7 } & preoperatív & posztoperatív & preoperatív & posztoperatív & preoperatív & posztoperatív \\
\hline 1 & 2 & 1 & 3 & 1 & 1 & 1 \\
\hline & 1 & 3 & 1 & 2 & 1 & 1 \\
\hline \\
\hline
\end{tabular}

Kutatásunkban sem a posztoperatív OR $(\mathrm{r}=0,0253)$, sem a zsíros degeneráció $(\mathrm{r}=0,2709)$, nem mutatott korrelációt a szakadás súlyosságával a Pearson-féle teszt alapján (4. és 5. ábra).

Összefüggés a Constant-pontszámmal: a vizsgálat során azt is megnéztük, hogy a rekonstrukció utáni OR-értéktôl, valamint a zsíros degeneráció stádiumától mennyiben függ a betegek CS-a. Bár az OR és a szakadás mértéke között van összefüggés, a Pearson-féle korrelációs próba alapján a korreláció nem volt szignifikáns $(\mathrm{r}=$ 0,582) (6. ábra). A zsíros degeneráció és a CS között sincs szignifikáns összefüggés $(\mathrm{r}=0,0223)$ (7. ábra).

Rerupturát négy esetben tapasztaltunk a mútét utáni MR-vizsgálat képein, ami egyezett a fizikális lelettel is;

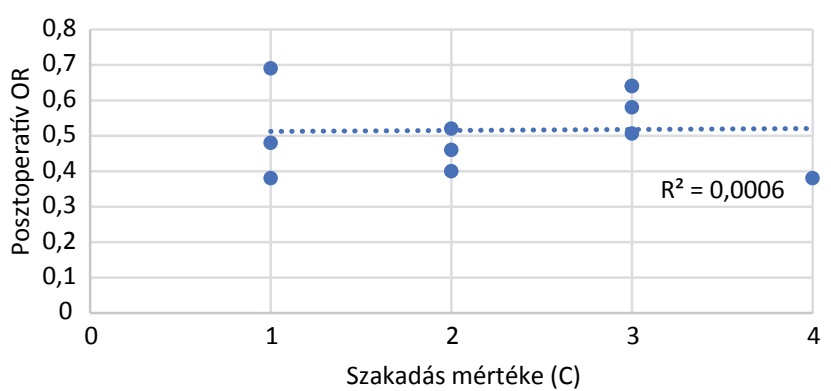

\begin{tabular}{l|l} 
4. ábra & A posztoperativ OR és a szakadás mértékének (C) összefüggése
\end{tabular} $\mathrm{OR}=$ kitöltöttségi arány

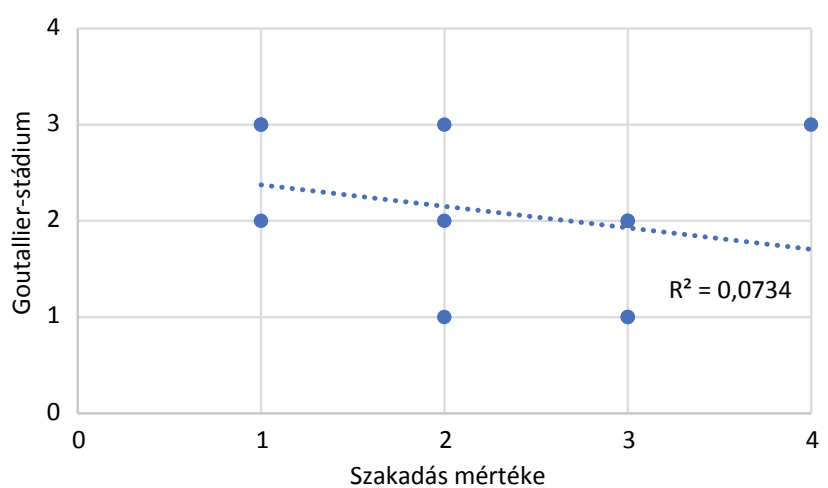

5. ábra $\mid$ A posztoperatív zsíros degeneráció és a szakadás mértékének (C) összefüggése

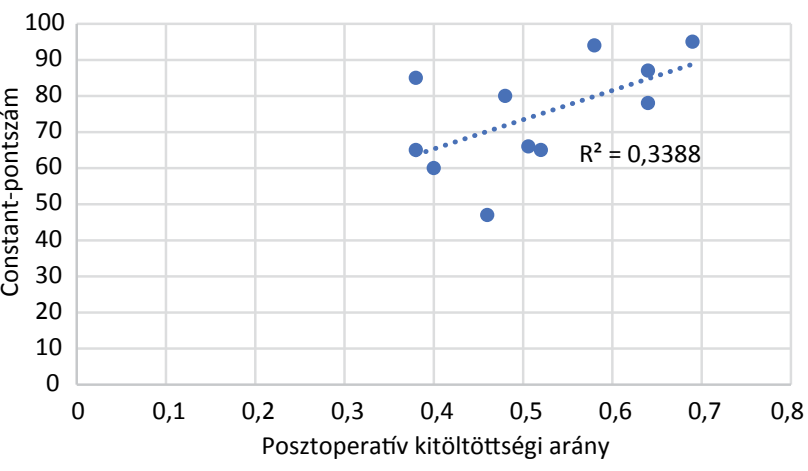

6. ábra

$$
\mid \begin{aligned}
& \text { A posztoperatív OR és a Constant-pontszám összefüggése } \\
& \text { OR = kitöltöttségi arány }
\end{aligned}
$$

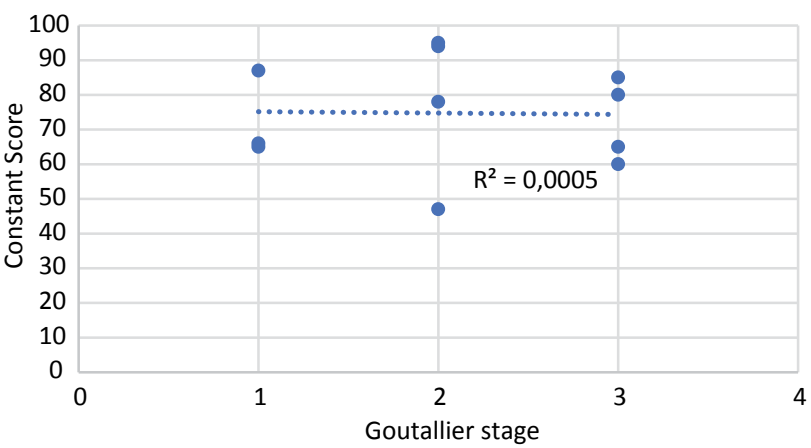

7. ábra

A posztoperatív zsíros degeneráció és a Constant-pontszám összefüggése

a funkcionális teszteknél érzékelhető volt az izom gyengesége, azonban a betegek aktív vállfunkciója szinte teljes volt, és az operáció előttinél kisebb fájdalomról számoltak be.

\section{Megbeszélés}

A rotátorköpeny-szakadás rekonstrukciója utáni zsíros degeneráció, illetve izomatrófia változásainak jellemzésére több vizsgálat is indult. Mellado és mtsai 28 betegnél teljes vastagságú ROK-szakadás esetében vizsgálta rekonstrukció után a zsíros degeneráció változását. A m. supraspinatus izomzat zsíros degenerációjának progresszióját 15 (54\%) váll esetében mutatták ki, és korrelációt találtak a 
szakadás mérete és a Goutallier-stádiumok változása között [18]. Vizsgálatunk eredményei alapján a zsíros degeneráció egy esetben sem mutatott javulást, ám ebben szerepet játszhat, hogy a kutatásunkban részt vevók átlagéletkora 12,1 ével haladta meg a Mellado és mtsai által vizsgált páciensekét (71,9 év szemben 59,8 évvel).

Gladstone és mtsai 38 (62 éves átlagéletkorú) beteg bevonásával vizsgálták a $\mathrm{m}$. supraspinatus rekonstrukciója után az izomállományban bekövetkező zsíros degeneráció és az atrófia mértékét, a mútét előtti állapottal összehasonlítva. Ebben a vizsgálatban az izomatrófia 18 (47\%) esetben progressziót, $\mathrm{l}(2,6 \%)$ esetben javulást mutatott, és az esetek felében nem változott. Az izom zsíros degenerációja egy esetben sem javult, 14 (37\%) páciensnél progrediált, és $24(63 \%)$ esetben a stádiumot tekintve nem változott [19]. A Klinikánkon végzett vizsgálatunk során a zsíros degeneráció 4 (37\%) esetben stagnált, és 7 $(63 \%)$ esetben progressziót mutatott, míg az atrófia mértékére használt Thomazeau-stádiumok 5 (45\%) betegnél stagnáltak, $5(45 \%)$ esetben progrediáltak, és 1 (10\%) esetben javultak.

Deniz és mtsai azt találták, hogy nem javul sem az atrófia, sem a zsíros degeneráció. Valamint az is kiderült, hogy nincs összefüggés a két tényező között, vagyis nem szükségszerúen változnak együtt. Tehát fokozódhat a zsírosodás mértéke az atrófia stagnálásával, és fordítva, a súlyosbodó atrófia mellett lehet változatlan a zsíros degeneráció $[20]$. Az izomatrófia és a zsíros degeneráció tekintetében mi sem találtunk szignifikáns javulást, és a kettő közötti korrelációt is cáfolták kutatási eredményeink $(\mathrm{r}=0,5307)$.

Lhee és mtsai szintén azt találták, hogy az atrófia az enyhe és a mérsékelt-súlyos mértékú szakadással rendelkező csoportok esetében is szignifikáns javulást mutat. Eredményeik alapján 60 év fölötti betegnél az enyhe szakadások esetén az atrófia javulása kisebb mértékú, mint a fiatalabb korcsoportokban, de a mérsékelt szakadások esetén nem mutatható ki ezen a téren szignifikáns különbség [21].

A 11 vizsgált beteg közül 9-nek kiváló vagy jó Constant-pontszáma született. A betegek elégedettségét saját bevallás alapján vizsgáltuk $0-10$-es skála segítségével. Itt a betegek véleménye alapján számolt átlag 8,45 pont volt, és csak 2 beteg számolt be 8 alatti elégedettségről. A VAS esetében 11 esetből 6 kiváló, l jó, 3 közepes és csak 1 rossz eredmény született.

Vizsgálatunk eredményei alapján megállapíthatjuk, hogy a 65 év feletti korcsoport esetében a teljes vastagságú rotátorköpeny-szakadás rekonstrukciója után az izomállomány zsíros degenerációja és atrófiája nem mutat jelentős javulást. Felmerülhet a kérdés, hogy miért lehet értelme mégis elvégezni a rotátorköpeny-ínrekonstrukciót. Erre a betegek életminőségi és fájdalomparaméterei adnak választ. Az 75-ös átlag-CS azt jelenti, hogy a rekonstrukciót követően a betegek nagyrészt fájdalommentesek, vállfunkciójuk jó, és mindennapi tevékenységeik során nem vagy csak kissé hátráltatja őket vállpanaszuk. Ezt a VAS-eredmények is alátámasztják: átlagban 8,45/10-re értékelték fájdalmukat. A mútéttel tehát jó életminőséget és alacsony fájdalomszintet értünk el. Az izom mennyiségi és minőségi állapotromlása ellenére tapasztalt fájdalomcsökkenés és életminőség-javulás legvalószínúbb biomechanikai magyarázata az lehet, hogy a rekonstrukció után a m. supraspinatus ín visszavarrásával a rotátorköpeny centralizáló funkciója visszaállítható. Ezzel együtt visszaáll az ismert erőpárok centralizáló hatása, és a humerusfej proximalizációja [22] megszúnik. Ezzel lehet összefüggésben az is, hogy a rekonstrukció után és a posztoperatív időszakban végzett gyógytorna hatására visszaáll a vállízület biomechanikája, és a mútét után kialakult reruptura esetén nem bomlik meg a humerusfejre ható erôpárok jótékony hatása.

Anyagi támogatás: A közlemény megírásával kapcsolatban a szerzők nem részesültek anyagi támogatásban.

Szerzői munkamegosztás: S. I., Sz. A.: A közlemény megírása, betegvizsgálat. W. M.: Betegvizsgálat, statisztika, a közlemény megírása. A. I., S. G.: A betegek mútéti kezelése, utóvizsgálata, gondozása, a közlemény megírása, véleményezése. A cikk végleges változatát valamennyi szerző elolvasta és jóváhagyta.

Érdekeltségek: A szerzőknek nincsenek érdekeltségeik.

\section{Irodalom}

[1] Melis B, DeFranco MJ, Chuinard C, et al. Natural history of fatty infiltration and atrophy of the supraspinatus muscle in rotator cuff tears. Clin Orthop Relat Res. 2010; 468: 1498-1505.

[2] Brooks CH, Revell WJ, Heatley FW. A quantitative histological study of the vascularity of the rotator cuff tendon. J Bone Joint Surg Br. 1992; 74: 151-153.

[3] Kang JR, Gupta R. Mechanisms of fatty degeneration in massive rotator cuff tears. J Shoulder Elbow Surg. 2012; 21: 175-180.

[4] Sallai I, Kővári E, Koteczki Á, et al. Functional outcome of arthroscopic rotator cuff repair. [Artroszkópos rotátorköpeny-rekonstrukció prospektív vizsgálata.] Orv Hetil. 2014; 155: 620626. [Hungarian]

[5] Kővári E, Koteczki Á, Kovács B, et al. Midterm outcome after rotator cuff reconstruction. [Rotátorköpeny-rekonstrukció utáni középtávú eredmények.] Orv Hetil. 2012; 153: 655-661. [Hungarian]

[6] Thompson WO, Debski RE, Boardman ND, et al. A biomechanical analysis of rotator cuff deficiency in a cadaveric model. Am J Sport Med. 1996; 24: 286-292.

[7] Tuite MJ, Sanford MF, Levey DS, et al. Rotator cuff injury MRI. Available from: http://emedicine.medscape.com/article/ 401714-overview [accessed: October 29, 2018]. Updated: Mar $14,2018$.

[8] Abtahi AM, Granger EK, Tashjian RZ. Factors affecting healing after arthroscopic rotator cuff repair. World J Orthop. 2015; 6: 211-220.

[9] Fuchs B, Weishaupt D, Zanetti M, et al. Fatty degeneration of the muscles of the rotator cuff: assessment by computed tomography versus magnetic resonance imaging. J Shoulder Elbow Surg. 1999; 8: 599-605. 
[10] Rulewicz GJ, Beaty S, Hawkins RJ, et al. Supraspinatus atrophy as a predictor of rotator cuff tear size: an MRI study utilizing the tangent sign. J Shoulder Elbow Surg. 2013; 22: e6-e10.

[11] Gerber C, Fuchs B, Hodler J. The results of repair of massive tears of the rotator cuff. J Bone Joint Surg. 2000; 82: 505-515.

[12] Galasso O, Riccelli DA, De Gori M, et al. Quality of life and functional results of arthroscopic partial repair of irreparable rotator cuff tears. Arthroscopy 2017; 33: 261-268.

[13] Snyder SJ, Pachelli AF, Del Pizzo W, et al. Partial thickness rotator cuff tears: results of arthroscopic treatment. Arthroscopy 1991; 7: 1-7.

[14] Constant CR, Gerber C, Emery RJ, et al. A review of the Constant score: modifications and guidelines for its use. J Shoulder Elbow Surg. 2008; 17: 355-361.

[15] Patte D. Classification of rotator cuff lesions. Clin Orthop Relat Res. 1990; 254: 81-86.

[16] Thomazeau H, Rolland Y, Lucas C, et al. Atrophy of the supraspinatus belly. Assessment by MRI in 55 patients with rotator cuff pathology. Acta Orthop Scand. 1996; 67: 264-268.

[17] Goutallier D, Postel JM, Bernageau J, et al. Fatty muscle degeneration in cuff ruptures. Pre- and postoperative evaluation by CT scan. Clin Orthop Relat Res. 1994; 304: 78-83.

[18] Mellado JM, Calmet J, Olona M, et al. Surgically repaired massive rotator cuff tears: MRI of tendon integrity, muscle fatty de- generation, and muscle atrophy correlated with intraoperative and clinical findings. Am J Roentgenol. 2005; 184: 1456-1463.

[19] Gladstone JN, Bishop JY, Lo IK, et al. Fatty infiltration and atrophy of the rotator cuff do not improve after rotator cuff repair and correlate with poor functional outcome. Am J Sports Med. 2007; 35: 719-728.

[20] Deniz G, Kose O, Tugay A, et al. Fatty degeneration and atrophy of the rotator cuff muscles after arthroscopic repair: does it improve, halt or deteriorate? Arch Orthop Trauma Surg. 2014; 134: 985-990.

[21] Lhee SH, Singh AK. Does magnetic resonance imaging appearance of supraspinatus muscle atrophy change after repairing rotator cuff tears? J Shoulder Elbow Surg. 2017; 26: 416-423.

[22] Keener JD, Wei AS, Kim HM, et al. Proximal humeral migration in shoulders with symptomatic and asymptomatic rotator cuff tears. J Bone Joint Surg Am. 2009; 91: 1405-1413.

(Sallai Imre dr., Budapest, Üllői út 78/b, II. em., 1082 e-mail: sallai.imre@semmelweis-univ.hu)

\section{PÁLYÁZATI FELHÍVÁS}

Dr. Fehér Jánosnak, a Semmelweis Egyetem II. sz. Belgyógyászati Klinika volt igazgatójának és az Orvosi Hetilap volt föszerkesztőjének emlékére létrehozott Dr. Fehér János Emlékére Alapítvány minden évben pályázatot ír ki egyetemi hallgatók, fiatal egyetemi oktatók és $\mathrm{PhD}$-hallgatók részére, akik a belgyógyászatban, különösen a hepatológiában végzett kutatási eredményeiket az Orvosi Hetilapban publikálják.

A kéziratot „Dr. Fehér János pályázat” megjelöléssel 2019. április 15-ig kell feltölteni az Orvosi Hetilap Editorial Manager rendszerébe.

A pályázathoz mellékelni kell a pályázó önéletrajzát.

A díj odaítélésérool az Alapítvány kuratóriuma dönt. A díj átadására a Markusovszky Lajos-ünnepségen, 2019. májusában kerül sor, ahol a nyertes pályázó rövid előadásban ismertetheti eredményeit.

A cikk a Creative Commons Attribution 4.0 International License (https://creativecommons.org/licenses/by/4.0/) feltételei szerint publikált Open Access közlemény, melynek szellemében a cikk bármilyen médiumban szabadon felhasználható, megosztható és újraközölhető, feltéve, hogy az eredeti szerző és a közlés helye, illetve a CC License linkje és az esetlegesen végrehajtott módosítások feltüntetésre kerülnek. (SID_1) 